\title{
Strategi Pemasaran Kopi Luwak pada UMKM Zhibond Coffee di Kabupaten Jember
}

\author{
Uki Diana Novitasari ${ }^{1 *}$, Andi Muhammad Ismail ${ }^{1}$ \\ ${ }^{1}$ Department of Agribusiness Management, Politeknik Negeri Jember \\ *ukidiana314@gmail.com
}

Submitted: 08 Mar 2021

Accepted: 24 May 2021

Published: 28 Jun 2021

\begin{abstract}
ABSTRAK
UMKM Zhibond Coffee merupakan sebuah usaha kopi yang terletak di perumahan Milenia blok E-26 kecamatan Kaliwates kabupaten Jember. Usaha ini memproduksi berbagai macam kopi salah satunya adalah kopi luwak yang merupakan produk unggulan dari UMKM Zhibond Coffee. Selama masa pandemi covid-19, UMKM Zhibond Coffee mengalami penurunan penjualan. Disamping itu terdapat kendala pemasaran diantaranya belum maksimalnya strategi pemasaran, sistem pembayaran klien yang masih molor, dan adanya pesaing usaha sejenis. Hal ini menjadi latar belakang untuk melakukan penelitian mengenai strategi pemsaran yang tepat untuk kemajuan UMKM Zhibond Coffee. Penelitian ini bertujuan untuk 1) Mengetahui faktor-faktor internal dan eksternal yang menjadi kekuatan, kelemahan, peluang serta ancaman dalam strategi pemasaran kopi pada UMKM Zhibond Coffee di Kabupaten Jember, 2) Menetapkan alternatif strategi pemasaran kopi pada UMKM Zhibond Coffee di Kabupaten Jember, 3) Menentukan prioritas strategi pemasaran kopi pada UMKM Zhibond Coffee di Kabupaten Jember. Metode pengolahan dan analisis data yang digunakan pada penelitiana ini adalah analisis SWOT dan metode QSPM yang digunakan untuk mengetahui strategi yang tepat pada UMKM Zhibond Coffee. Hasil penelitian menunjukkan bahwa perusahaan pada sel V dan prioritas strategi yang diterapkan adalah menjaga kualitas dan stabilitas bahan baku agar produk dapat bersaing.
\end{abstract}

Kata kunci: Strategi, Pemasaran, SWOT, QSPM

\section{ABSTRACT}

UMKM Zhibond Coffee is a coffee business located in the Millenia housing block E-26, Kaliwates sub-district, Jember district. This business produces various kinds of coffee, one of which is civet coffee, which is a superior product from UMKM Zhibond Coffee. During the Covid-19 pandemic, UMKM Zhibond Coffee experienced a decline in sales. In addition, there are marketing constraints, including the inadequate marketing strategy, delayed client payment systems, and the existence of similar business competitors. This becomes the background for conducting research on the right marketing strategy for the advancement of UMKM Zhibond Coffee. This study aims to 1) Determine the internal and external factors that are the strengths, weaknesses, opportunities and threats in the coffee marketing strategy at UMKM Zhibond Coffee in Jember Regency, 2) Determine alternative coffee marketing strategies at UMKM Zhibond Coffee in Jember Regency, 3) Determine the priority of coffee marketing strategies at UMKM Zhibond Coffee in Jember Regency. The data processing and analysis methods used in this study are the SWOT analysis and the QSPM method used to determine the right strategy at UMKM Zhibond Coffee. The results showed that the company in cell V and the priority of the strategy implemented was to maintain the quality and stability of raw materials so that the products could compete.

Keyword: Strategy, Marketing, SWOT, QSPM

\section{Pendahuluan}

Kopi merupakan salah satu bahan minuman yang sangat disukai oleh masyarakat di seluruh belahan dunia mulai dari remaja hingga dewasa. Meminum kopi menjadi salah satu kegiatan yang biasa dilakukan baik sebelum melakukan aktivitas maupun setelah beraktivitas. Kopi merupakan komoditas perkebunan yang memiliki nilai ekonomis yang tinggi. Indonesia adalah salah satu penghasil kopi terbesar keempat didunia setelah Brazil, Vietnam dan Colombia dengan nilai produksi pada tahun 2015 
sebesar 639.000 ton/tahun (Kementerian Pertanian, 2015). Produksi kopi cenderung mengalami peningkatan dari tahun 2016 sampai tahun 2018. Pada tahun 2016 sekitar 632,00 ribu ton, pada tahun 2017 menjadi 685,80 ribu ton dan pada tahun 2018 sekitar 685,79 ribu ton (Badan Pusat Statistik, 2018).

Daerah penghasil kopi terbesar di Indonesia yaitu Sumatera Selatan, Lampung dan Jawa Timur (Kementerian Pertanian, 2018). Jember adalah salah satu daerah penghasil kopi di Jawa Timur yang memiliki produk unggulan komoditas kopi. Jenis kopi yang memiliki banyak peminat adalah kopi robusta. Variasi produk kopi juga beraneka ragam mulai dari kopi bubuk, kopi instan hingga minuman berbahan dasar kopi. Kopi bubuk merupakan kopi yang diolah dengan cara digiling hingga membentuk butiran-butiran kopi yang halus sehingga memudahkan dalam proses penyeduhan. Banyaknya variasi produk kopi menyebabkan tingginya konsumsi kopi sehingga menciptakan banyak peluang bagi pengusaha kopi dalam mengembangkan usahanya.

UMKM Zhibond Coffee merupakan salah satu industri kopi di Jember yang berdiri sejak tahun 2011. UMKM Zhibond Coffee beralamat di Perumahan Milenial blok E-26 Kecamatan Kaliwates Kabupaten Jember. Kopi yang ditawarkan yaitu kopi robusta, arabika, liberika dan luwak. Kopi yang dipasarkan dikemas dalam kemasan 100 gram dengan harga yang berbeda sesuai dengan jenisnya. Proses produksi kopi dilakukan sebulan sekali dengan produksi mencapai \pm 1 ton kopi.

Kopi luwak merupakan salah satu produk kopi unggulan dari UMKM Zhibond Coffee. Selain memiliki kualitas serta kuantitas yang baik dibandingkan jenis kopi lainnya, proses produksi kopi luwak juga terbilang cukup susah. Mulai dari pengumpulan biji kopi dari feses luwak, pencucian hingga pemilihan biji kopi yang sesuai standar yang ditentukan. Jadi tidak heran apabila kopi luwak memiliki cita rasa yang nikmat dan nilai jual yang sangat tinggi.

Selama masa pandemi covid-19, volume penjualan pada UMKM Zhibond Coffee mengalami penurunan hingga $40 \%$ dari target penjualan. Kopi luwak merupakan kopi yang mengalami penurunan paling rendah dibandingkan jenis kopi lainnya. Disamping itu terdapat kendala dalam pemasaran pada UMKM Zhibond Coffee yaitu persaingan ketat antar usaha sejenis sehingga akan mempengaruhi eksistensi suatu usaha. Kendala lain yang dihadapi UMKM Zhibond Coffee ini yaitu sistem pembayaran klien yang sering molor, belum terealisasinya program loyalitas pelanggan dan pengelolaan manajemen yang belum efektif. Saat ini pesaing produk sejenis di daerah Jember semakin bertambah. Dengan adanya pesaing memicu pemilik usaha untuk melakukan pengembangan produk guna mempertahankan kepercayaan konsumen terhadap produk yang ditawarkan. Pengusaha harus mampu menciptakan inovasi serta melakukan metode pemasaran yang tepat sehingga usaha yang dijalankan dapat bersaing dan berkembang.

Metode pemasaran yang digunakan pada UMKM Zhibond Coffee adalah dengan memasarkan produk di mall, outlet dan pusat oleh-oleh. Untuk meningkatkan daya saing kopi di UMKM Zhibond Coffee dapat dilakukan upaya pembenahan sistem pemasaran dan menentukan strategi untuk menarik konsumen dalam pemilihan produk serta mengembangkan penguasaan pasar. Hal ini yang menjadi latar belakang untuk melakukan penelitian mengenai strategi pemasaran untuk meningkatkan dan mengembangkan pemasaran kopi di UMKM Zhibond Coffee.

Berdasarkan uraian diatas dapat dilihat permasalahan yang dihadapi UMKM Zhibond Coffee maka peneliti menetapkan strategi pemasaran dengan menggunakan metode analisis analisis IFAS, EFAS, SWOT dan QSPM yang digunakan untuk merumuskan alternatif strategi pemasaran serta menentukan prioritas strategi yang sesuai dengan kondisi internal maupun eksternal perusahaan. Dengan adanya hasil analisis, UMKM Zhibond Coffee diharapkan mampu mengembangkan strategi pemsaran produk serta menetapkan strategi dalam bersaing untuk mengahadapi kemungkinan munculnya perubahan yang terjadi dilingkungan perusahaan.

\section{Metode Penelitian}

Penelitian ini mengunakan metode deskriptif yaitu metode yang bertujuan untuk 
menggambarkan sifat sesuatu yang tengah berlangsung pada saat riset dilakukan dan untuk memeriksa sebab-sebab dari suatu gejala tertentu. Untuk mendapatkan data yang valid dalam metode ini dilakukan cara survey, dimana peneliti tidak perlu memperhitungkan hubungan antara variabel-variabel karena data yang digunakan sudah tersedia dan bukan menguji hipotesis untuk menganalisis permasalahan

Penelitian ini dilakukan untuk mengidentifikasi faktor internal dan faktor eksternal yang kemudian menentukan strategi yang tepat pada UMKM Zhibond Coffee agar memperluas pemasaran didalam mencapai pasar sasaran yang tepat dan mampu mempertahankan usahanya ditengah persaingan yang tinggi. Metode pengumpulan data pada penelitian ini dilakukan dengan Metode Purposive Sampling yang teknik penentuan sampel dengan pertimbangan tertentu (Sugiyono,2016:85).

\subsection{Definisi Variabel Penelitian}

Variabel penelitian adalah atribut, sifat atau nilai dari orang, obyek atau kegiatan yang memiliki variasi tertentu dan ditetapkan oleh peneliti untuk dapat dipelajari serta ditarik kesimpulannya. (Sugiyono,2016:38).

Faktor internal merupakan faktor yang berasal dari dalam UMKM Zhibond Coffee yang berpengaruh dalam penjualan produk. Dalam penelitian ini faktor-faktor internal akan diklasifikasikan menjadi kekuatan (strengths) dan kelemahan (weaknesses).

a. Pasar dan Pemasaran merupakan faktor internal pada UMKM Zhibond Coffee yang dilakukan dengan menciptakan rencanarencana yang strategis untuk memuaskan kebutuhan dan keinginan konsumen. Pasar adalah suatu tempat bertemunya penjual dan pembeli. Sedangkan pemasaran merupakan proses komunikasi tertentu untuk memberikan informasi yang berkaitan dengan suatu produk guna memenuhi dan memuaskan keinginan konsumen.

b. Keuangan dan akuntansi merupakan suatu informasi yang memegang peranan penting dalam suatu perusahaan karena berhubungan dengan kinerja perusahaan. Keuangan adalah pengelolaan dana yang dimiliki perusahaan untuk kepentingan strategi dimasa depan. Sedangkan akuntansi adalah suatu aktivitas pencatatan hasil keuangan perusahaan yang bertujuan memberikan informasi terkait laporan keuangan.

c. Kegiatan Produksi merupakan kegiatan yang dilakukan dalam mengatur sistem pengelolaan suatu produk pada UMKM Zhibond Coffee dengan sumber daya yang dimiliki secara efektif untuk menghasilkan produk yang diinginkan.

d. Sumber daya manusia merupakan tenaga kerja yang bergerak dalam menentukan perkembangan serta melakukan aktivitas produksi pada UMKM Zhibond Coffee untuk meningkatkan mutu usaha.

Faktor Ekternal merupakan faktor yang berasal dari luar UMKM Zhibond Coffee yang dapat berpengaruh terhadap strategi pemasaran produk.

1. Konsumen merupakan pembeli atau pengguna jasa yang melakukan pembelian untuk memenuhi kebutuhan.

2. Pesaing merupakan perusahaan yang menghasilkan atau penjual produk sejenis dengan produk yang memiliki karakteristik mirip dengan UMKM Zhibond Coffee.

3. Demografi merupakan keadaan kependudukan suatu wilayah sehingga mempengaruhi pemasaran produk kopi pada UMKM Zhibond Coffee.

4. Saluran distribusi merupakan kegiatan dalam penyaluran produk yang ditentukan oleh perusahaan untuk memberikan produk kepada konsumen.

\subsection{Intrumen Penelitian}

Penelitian ini menggunakan instrumen penelitian dalam bentuk kuesioner, observasi dan wawancara yang akan ditujukan pada pemilik dan bagian pemasaran UMKM Zhibond Coffee untuk memperoleh informasi secara langsung dan untuk menganalisis lingkungan usaha serta digunakan dalam penentuan strategi pemasaran dengan analisis SWOT.

\subsection{Prosedur Pengumpulan Data}

Dalam pengumpulan data, langkah-langkah yang dilakukan oleh peneliti adalah : 
Pengumpulan data primer diperoleh secara langsung dari perusahaan yang diteliti. Pengambilan data primer dilakukan dengan cara berikut.

a. Penelitian lapang atau observasi yaitu kegiatan pengumpulan data yang dilakukan secara langsung dengan mengamati objek maupun fenomena yang terjadi pada lingkungan industri.

b. Metode kuesioner yaitu metode pengumpulan data dengan memberikan angket yang berisikan pertanyaan tertutup sebagai alat pengumpulan data pokok.

c. Metode wawancara yaitu kegiatan tanya jawab yang dilakukan secara langsun oleh peneliti dengan narasumber atau pemilik usaha ataupun pihak yang seusuai dengan tema penelitian.

Pengumpulan data sekunder diperoleh secara tidak langsung dari subjek penelitian dan dari lembaga lain yang sesuai dengan tema penelitian. Untuk pengumpulan data sekunder yaitu dokumen terkait dari UMKM Zhibond Coffee serta literatur atau kepustakaan yang berhubungan dengan strategi pemasaran produk di dalam suatu unit usaha.

\subsection{Teknik Analisis}

Setelah melakukan identifikasi faktor internal dan eksternal perusahaan, kemudian dilakukan perumusan faktor-faktor strategis internal dalam kerangka Strenght dan Weakness. Dan melakukan perumusan faktor-faktor eksternal dengan menyusu peluan dan ancaman yang kemudia dilakukan perhitungan bobot, rating, dan menjumlahkan skor pembobotan untuk memperoleh skor total.

Setelah itu melakukan identifikasi menggunakan matriks IE yang meiputi kekuatan internak dan kondisi eksternal yang dihadapi perusahaan.

Setelah melakukan penyusunan matriks IE, kemudian dilakukan analisis SWOT untuk mengembangkan 4 tipe strategi alternatif yaitu strategi SO (Strenght-Opportunity), strategi WO (Weakness-Opportunity), strategi ST (StrenghtThreats), dan strategi WT (Weakness-Threats).

Tahap akhir yaitu dengan melakukan pemilihan alternatif strategi dengan melakukan pengambilan keputusan paling tepat yang dapat digunakan oleh perusahaan dengan menggunakan matriks QSPM yaitu meringkas dan mengevaluasi alternatif strategi yang dapat digunakan secara objekstif berdasarkan faktorinternal dan eksternal yang telah diidentifikasi sebelumnya

\section{Hasil dan Pembahasan}

\subsection{Hasil Analisis SWOT}

\subsubsection{Identifikasi Kekuatan dan Kelemahan}

Berdasarkan analisis lingkungan yang telah dilakukan, terdapat faktor-faktor yang dapat dikelompokkan menjadi dua faktor, yaitu kekuatan dan kelemahan yang dimiliki oleh UMKM Zhibond Coffee. Faktor-faktor tersebut antara lain :

a. Kekuatan

- Stabilitas harga bahan baku yang relatif tetap

Kerjasama dengan pemasok merupakan salah satu hal yang penting, karena pemasok sangat berperan dalam memenuhi kebutuhan bahan baku. Pemilik UMKM Zhibond Coffee selalu menjalin hubungan baik dengan para pemasok sehingga biji kopi yang dipasok memiliki harga yang stabil dan memiliki pemasok tetap.

- Promosi yang dilakukan secara online dan offline.

Salah satu keunggulan usaha yang dilakukan oleh UMKM Zhibond Coffee adalah promosi yang dilakukan secara online melalui media sosial. Hal tersebut akan memberikan akses pemasaran yang luas dengan biaya yang dikeluarkan relatif terjangkau. Selain itu perusahaan akan terhubung dengan pelanggan secara real time dan dapat memungkinkan untuk bida mendapatkan feedback yang instan dari para konsumen.

- Luasnya pangsa pasar

Kopi luwak dipasarkan di mall dan pusat oleh-oleh.Kopi luwak juga telah dipasarkan dibeberapa daerah di Indonesia seperti Jember, Malang, Surabaya, Jakarta, Sulawesi, Sumatera, Kalimantan, Bali. Untuk mempertahankan pangsa pasar perusahaan akan dihadapkan oleh tantangan dalam 
bersaing. Oleh sebab itu harus dapat menerapkan strategi pemasaran yang tepat untuk menciptakan produk yang sesuai dengan keinginan dan kebutuhan konsumen.

- Adanya perizinan dari pemerintah berupa nomor PIRT, Sertifikat Halal, SNI dan Trademark

Perizinan dari pemerintah berupa nomor PIRT akan memudahkan perusahaan dalam memasarkan produknya secara luas karena sudah layak edar dan mutu dari produk sudah terjamin. Konsumen akan lebih percaya terhadap kualitas produk karena telah memiliki sertifikat halal dimana jaminan penerapan standar yang sesuai dengan norma agama, industri, dan bisnis. Selain memiliki nomor PIRT dan sertifikat halal, UMKM Zhibond Coffee juga telah berstandar SNI dimana mutu dari produk telah terjamin kualitasnya. UMKM Zhibond Coffee juga memiliki trademark atau merek dagang yang mana akan memudahkan konsumen dalam membedakan produk satu dan lainnya dalam kategori yang sama.

- Bahan baku yang berkualitas

Bahan baku kopi luwak yang digunakan oleh UMKM Zhibond Coffee berupa olahan dalam bentuk green bean. Dalam proses pengolahannya, UMKM Zhibond Coffee menggunakan standar medium roasted untuk kopi luwak sangrai dan bubuk. Waktu yang diperlukan 7 hingga 15 menit dan suhu $180^{\circ} \mathrm{C}$. Sedangkan kopi luwak bubuk diperlukan waktu 7 hingga menit dengan menggunakan greader size yang paling halus. Kualitas biji kopi luwak memiliki kualifikasi yang baik, hal ini dikarenakan pemasok yang dipilih memiliki biji kopi yang berkualitas.

- Bahan baku yang mudah didapat

UMKM Zhibond Coffee bekerja sama dengan beberapa pemasok kopi luwak dari beberapa daerah diantaranya petani dari kebun rakyat Durjo, Situbondo, Tanggul. Petani dan pemasok sebelumnya sudah melalui pendampingan dengan karyawan UMKM Zhibond Coffee sehingga dari kopi luwak yang awalnya dipanen dengan kualitas rendah sekarang sudah memperhatikan kualitas biji kopi luwak.

- Tenaga kerja yang berkompeten
UMKM Zhibond Coffee memiliki karyawan sebanyak 6 orang. Setiap karyawan memiliki kemampuan dan keahlian yang baik sesuai dengan bidangnya. Beberapa karyawan sering kali mengikuti perlombaan bisnis dan telah memenangkan beberapa piagam bisnis.

b. Kelemahan

- Belum memiliki outlet resmi

Untuk promosi yang dilakukan oleh UMKM Zhibond Coffee masih memanfaatkan teknologi yang sudah berkembang seperti media online. Untuk pemasaran offline dilakukan melalui mulut ke mulut.

- Harga kopi cenderung lebih mahal

Kopi luwak dikenal sebagai salah satu jenis kopi termahal karena proses produksi yang panjang dan jumlah panen tidak sebesar biji kopi lainnya. Harga kopi luwak di UMKM Zhibond Coffee berkisar Rp.800.000/kg. Kualitas serta biaya-biaya lain yang dikeluarkan menjadi salah satu alasan tingginya harga kopi luwak.

- Pengelolaan manajemen akuntansi yang masih belum teratur

Dalam pencatatan pengelolaan penurunan dan kenaikan pendapatan, pemilik UMKM Zhibond Coffee tidak melakukan pembukuan secara rutin. Selain itu, saaat kekurangan dana pemilik menambahkan dana pribadi untuk modal usaha guna membantu kelancaran proses produksi selanjutnya.

- Belum memiliki rumah produksi yang sesuai dengan standar

Tempat produksi kopi masih dilakukan di rumah pemilik. Rumah produksi adalah salah satu bagian penting dalam memperlancar berjalannya proses produksi. UMKM Zhibond Coffee belum memiliki rumah produksi resmi. Proses produksi kopi masih dilakukan dirumah pemilik dengan tempat yang terbatas. Hal tersebut membuat proses produksi berjalan lambat.

\subsubsection{Identifikasi Peluang dan Ancaman}

Terdapat faktor-faktor yang dapat dikelompokkan menjadi dua faktor, yaitu peluang dan ancaman yang dimiliki oleh UMKM 
Zhibond Coffee. Faktor-faktor tersebut antara lain :

a. Peluang

- Tingginya loyalitas konsumen terhadap produk kopi luwak

Loyalitas konsumen merupakan salah satu faktor penting agar usaha tersebut memiliki pelanggan yang selalu membeli produk dari perusahaan yang disukai. Apabila konsumen loyal terhadap produk kopi luwak pada UMKM Zhibond Coffee maka akan meningkatkan volume penjualan produk kopi luwak.

- Kepuasan konsumen terhadap produk

Suatu usaha akan berjalan lebih lancar apabila pemilik usaha selalu memperhatikan kepuasan konsumen saat menerima produk yang diberikan. Jika konsumen merasa puas dengan produk yang diberikan maka akan ada kemungkinan menjadi konsumen tetap. Oleh sebab itu, pemilik harus memperhatikan kepuasan konsumen konsumen sangat penting untuk merencanakan rencana usaha kedepannya.

- Produk kopi luwak memberikan manfaat yang lebih baik

Kopi luwak memiliki kandungan kafein yang lebih rendah dibandingkan kopi lainnya seperti kopi toraja, kopi aceh, dan lainnya. Rendahnya kadar kafein pada biji kopi luwak disebabkan oleh keistimewaan proses fermentasi alami dalam sistem pencernaan hewan luwak yang mampu mengurangi kadar kafein kopi. Selain itu kopi juga juga memiliki banyak manfaat untuk kesehatan diantaranya mencegah kanker, sumber antioksidan, cegah batu empedu dan berbagai manfaat lainnya.

- Adanya segementasi pasar yang sesuai dengan kebutuhan konsumen

Segmentasi pasar merupakan proses dalam mengelompokkan konsumen kedalam keadaan yang lebih homogen yang dapat dibagi dalam hal kebutuhan, karakteristik ataupun perilaku yang mungkin akan memerluka produk-produk dan strategi pemasaran tertentu untuk menjangkaunya. Secara demografik, UMKM Zhibond Coffee menargetkan kopi luwak untuk masyarakat kalangan menengah atas karena harganya yang cukup mahal. Harga dari kopi luwak sendiri adalah Rp.80.000 per 100gram.

- Target pasar tertuju secara jelas.

Target pasar dari kopi luwak yaitu pekerja yang berjenis kelamin laki-laki. Hal ini didasari oleh pria yang menjadi penikmat kopi cenderung memilih kopi yang lebih sehat karena hal tersebut akan berpengaruh terhadap kesehatan. Salah satunya adalah kopi luwak yang memiliki kafein lebih rendah didandingkan dengan jenis kopi lainnya. Selain itu karna harga yang cukup mahal sebagian besar konsumennya adalah masyarakat menengah keatas.

- Kegiatan pemasaran mempermudah dan memeprlancar penyampaian produk kepada konsumen.

Adanya kegiatan pemasaran akan membantu suatu perusahaan lebih dikenal oleh masyarakat dari beberapa daerah. Kegiatan pemasaran melibatkan perantara yang terhubung erat dengan konsumen oleh sebab itu produk akan dengan mudah dipasarkan dan dikenal oleh masyarakat luas.

\section{b. Ancaman}

- Banyaknya pesaing dengan produk sejenis

Adanya beberapa pesaing dengan produk sejenis merupakan suatu ancaman sekaligus tantangan bagi perusahaan. adanya produk sejenis akan menimbulkan persaingan yang ketat sehingga perlu dilakukan inovasi pada produk kopi luwak di UMKM Zhibond Coffee dengan memiliki strategi pemasaran yang tepat.

- Pesaing yang selalu berinovasi

Perusahaan dituntut selalu menciptakan inovasi untuk meningkatkan nilai jual pada produk. Menciptakan inovasi pada produsk merupakan kunci untuk memanagkan persaingan usaha. Selain itu dengan adanya inovasi pada produk akan membuat produk menarik bagi konsumen. Pesaing UMKM Zhibond Coffee selalu mengembangkan inovasinya sehingga membuat UMKM Zhibond harus mempertahankan bahkan menngkatkan kualitas produk agar tidak kalah kalah dengan pesaingnya.

- Belum memiliki ekspedisi

Penjualan kopi luwak sangat luas, sehingga perusahaan perlu mengirimkan produk yang 
akan dikirim keluar kota melalui ekspedisi.UMKM Zhibond Coffee belum memiliki ekpedisi sehingga untuk biaya ongkos kirim mash ditanggung konsumen

\subsubsection{Matriks IFAS}

Setelah mengidentifikasi semua faktorfaktor internal yang ada pada UMKM Zhibond Coffee meliouti keuatan dan kelemahan, selanjutnya dilakukan pembobotan dan pemberian peringkat atau rating untuk mengetahui skor yang di dapat.

Table 1. Matriks IFAS

\begin{tabular}{|c|c|c|c|c|}
\hline \multirow{2}{*}{ No } & Faktor Internal & \multirow{2}{*}{ Bobot } & \multirow{2}{*}{ Peringkat } & \multirow{2}{*}{$\begin{array}{l}\text { Skor } \\
\text { Nilai }\end{array}$} \\
\hline & Kekuatan & & & \\
\hline 1. & $\begin{array}{l}\text { Stabilitas harga bahan } \\
\text { baku yang relatif tetap }\end{array}$ & 0,11 & 3,0 & 0,32 \\
\hline 2. & $\begin{array}{l}\text { Promosi yang dilakukan } \\
\text { secara online dan offline }\end{array}$ & 0,11 & 4,0 & 0,43 \\
\hline 3. & Luasnya pangsa pasar & 0,14 & 3,5 & 0,50 \\
\hline 4. & $\begin{array}{l}\text { Adanya perizinan dari } \\
\text { pemerintah berupa } \\
\text { nomor PIRT, Sertifikat } \\
\text { Halal, SNI dan Trademark }\end{array}$ & 0,05 & 2,0 & 0,11 \\
\hline 5. & $\begin{array}{l}\text { Bahan baku yang } \\
\text { berkualitas }\end{array}$ & 0,14 & 3,5 & 0,50 \\
\hline 6. & $\begin{array}{l}\text { Bahan baku yang mudah } \\
\text { didapat }\end{array}$ & 0,11 & 3,0 & 0,32 \\
\hline 7. & $\begin{array}{l}\text { Tenaga kerja yang } \\
\text { berkompeten }\end{array}$ & 0,11 & 3,5 & 0,38 \\
\hline \multicolumn{5}{|c|}{ Kelemahan } \\
\hline 8. & $\begin{array}{l}\text { Belum memiliki outlet } \\
\text { resmi }\end{array}$ & 0,07 & 1,5 & 0,11 \\
\hline 9. & $\begin{array}{l}\text { Harga kopi cenderung } \\
\text { lebih mahal }\end{array}$ & 0,04 & 1,5 & 0,05 \\
\hline 10. & $\begin{array}{l}\text { Pengelolaan manajemen } \\
\text { akuntansi yang masih } \\
\text { belum teratur }\end{array}$ & 0,07 & 2,5 & 0,18 \\
\hline 11. & $\begin{array}{l}\text { Belum memiliki rumah } \\
\text { produksi yang sesuai } \\
\text { dengan standar }\end{array}$ & 0,05 & 1,5 & 0,08 \\
\hline & Total & 1,00 & & 2,97 \\
\hline
\end{tabular}

Hasil dari matriks IFAS adalah menunjukkan bahwa pemberian bobot dan peringkat mendapatkan hasil skor IFAS sebesar 2,97. Skor total tersebut menunjukkan bahwa UMKM Zhibond Coffee memiliki posisi yang kuat, karena skor total internal berada diatas skor rata-rata yaitu 2,5. Dalam hal ini UMKM Zhibond Coffee mengatasi kelemahannya dengan memanfaatkan kekuatan internal yang ada pada perusahaan. Kekuatan utama yang dimiliki oleh UMKM Zhibond Coffee adalah promosi yang dilakukan secara online dan offline serta bahan baku yang berkualitas dengan skor 0,50. Kelemahan utama yang dimiliki oleh
UMKM Zhibond Coffee yaitu pengelolaan manajemen akuntansi yang masih belum teratur dengan skor 0,18 .

\subsubsection{Matriks EFAS}

Setelah mengidentifikasi semua faktorfaktor eksternal yang ada pada UMKM Zhibond Coffee meliputi peluang dan ancaman. Selanjutnya yaitu dilakukan pembobotan dan pemberian peringkat atau rating.

Table 2. Matriks EFAS

\begin{tabular}{|c|c|c|c|c|}
\hline \multirow{2}{*}{ No } & Faktor Eksternal & \multirow{2}{*}{ Bobot } & \multirow{2}{*}{ Peringkat } & \multirow{2}{*}{$\begin{array}{l}\text { Skor } \\
\text { Nilai }\end{array}$} \\
\hline & Peluang & & & \\
\hline 1. & $\begin{array}{l}\text { Tingginya loyalitas } \\
\text { konsumen terhadap } \\
\text { produk kopi luwak }\end{array}$ & 0,13 & 3,5 & 0,47 \\
\hline 2. & $\begin{array}{l}\text { Kepuasan konsumen } \\
\text { terhadap produk }\end{array}$ & 0,13 & 4,0 & 0,53 \\
\hline 3. & $\begin{array}{l}\text { Produk kopi luwak } \\
\text { memberikan manfaat } \\
\text { yang lebih baik }\end{array}$ & 0,12 & 3,0 & 0,35 \\
\hline 4. & $\begin{array}{l}\text { Adanya segementasi } \\
\text { pasar yang sesuai dengan } \\
\text { kebutuhan konsumen }\end{array}$ & 0,08 & 3,0 & 0,25 \\
\hline 5. & $\begin{array}{l}\text { Target pasar tertuju } \\
\text { secara jelas }\end{array}$ & 0,10 & 3,5 & 0,35 \\
\hline 6. & $\begin{array}{l}\text { Kegiatan pemasaran } \\
\text { mempermudah dan } \\
\text { memperlancar } \\
\text { penyampaian produk } \\
\text { kepada konsumen }\end{array}$ & 0,10 & 3,5 & 0,35 \\
\hline \multicolumn{5}{|c|}{ Ancaman } \\
\hline 7. & $\begin{array}{l}\text { Banyaknya pesaing } \\
\text { dengan produk sejenis }\end{array}$ & 0,10 & 2,5 & 0,25 \\
\hline 8. & $\begin{array}{l}\text { Pesaing yang selalu } \\
\text { berinovasi }\end{array}$ & 0,09 & 1,5 & 0,15 \\
\hline 9. & Belum memiliki ekspedisi & 0,13 & 1,5 & 0,20 \\
\hline & Total & 1,00 & & 2,90 \\
\hline
\end{tabular}

Berdasarkan mastriks EFAS tersebut dapat menunjukkan bahwa pemberian bobot dan peringkat mendapatkan hasil skor EFAS sebesar 2,90. Berdasarkan perolehan skor nilai tersebut menunjukkan bahwa UMKM Zhibond Coffee mampu merespon faktor eksternal dengan baik dan memanfaatkan peluang untuk mengatasu ancaman yang dihadapi perusahaan. Peluang utama pada UMKM Zhibond Coffee yaitu kepuasan konsumen terhadap produk dengan skor nilai 0,53. Sedangkan ancaman pada UMKM Zhibond Coffee yaitu banyaknya pesaing dengan produk sejenis dengan skor nilai 0,25 . 


\subsubsection{Matriks IE}

Berikut ini aldah penilaian matriks IE pada UMKM Zhibond Coffee dapat dilihat pada gambar 4.1 berikut ini:

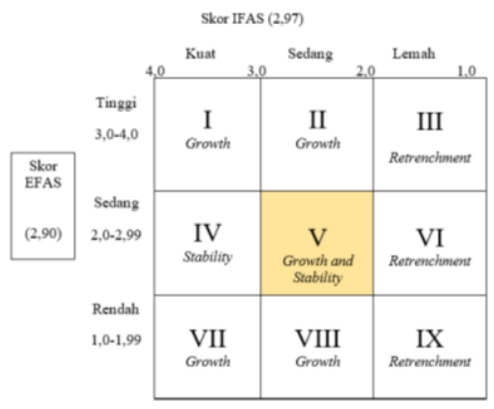

Figure 1. Matriks IE

Dari gambar diatas dapat diketahui rata-rata IFAS sebesar 2,97 dan nilai rata-rata EFAS sebesar 2,90 yang dapat menunjukkan titik UMKM Zhibond Coffee berada pada sel V. Pada titik ini strategi yang tepat digunakan yaitu Growth and Stability yang artinya berkembang dan mempertahankan. Strategi yang dapat diterapkan UMKM Zhibond Coffee yaitu pengembangan produk dan peningkatan pada manajemen operasional perusahaan. Strategi pengembangan produk yang tepat dapat dilakukan UMKM Zhibond Coffee yaitu dengan melakukan inovasi dan variasi pada produk kopi luwak seperti rasa, bentuk, dan kemasan. Keamanan pada produk harus terjamin. Mempertahankan mutu produk juga sangat penting dilakukan untuk mencegah timbulnya kekecewaan pada konsumen. Selain itu dengan mempertahankan mutu produk perusahaan bisa menekan biaya karena tidak melakukan pengerjaan dan pengecekan ulang produk.

\subsubsection{Matriks SWOT}

Setelah melakukan analisis lingkungan faktor internal dan analisis lingkungan faktor eksternal pada perusahaan, maka dilakukan penyusunan strategi alternatif berdasarkan analisis SWOT. Analisis matriks SWOT menghasilkan 4 strategi alternatif yaitu strategi (SO) strategi (WO), strategi (ST), dan strategi (WT). hasil dar analisis SWOT pada UMKM Zhibond Coffee dapat dilihat pada gambar 4.2 berikut :

\begin{tabular}{|c|c|c|}
\hline \multirow[b]{2}{*}{ EFAS } & Kekuatan (Strenghts) S & Kelemahan (Weakness) W \\
\hline & $\begin{array}{l}\text { 1.Stabilitas harga bahan baku yang relatif tetap } \\
\text { 2.Promosi yang dilakukan secara online dan } \\
\text { offline } \\
\text { 3.Luasnya pangsa pasar } \\
\text { 4.Adanya perizinan dari pemerintah berupa } \\
\text { PIRT, Srtifikat Halal, SNI dan Trademark } \\
\text { 5.Bahan baku yang berkualitas } \\
\text { 6.Bahan baku yang mudah didapat } \\
\text { 7.Tenaga kerja yang berkompeten }\end{array}$ & $\begin{array}{l}\text { 1. Belum memiliki outlet resmi } \\
\text { 2. Harga kopi cenderung lebih mahal } \\
\text { 3. Pengelolaan manajemen akuntansi yang masih belum } \\
\text { teratur } \\
\text { 4. Belum memiliki rumah produksi yang sesuai dengan } \\
\text { standar }\end{array}$ \\
\hline Peluang (opportunities) 0 & Strategi SO & Strategi Wo \\
\hline $\begin{array}{l}\text { 1. Tingginya loyalitas konsumen terhadap produk } \\
\text { kopi luwak } \\
\text { 2. Kepuasan konsumen terhadap produk } \\
\text { 3. Produk kopi luwak memberikan manfaat yang } \\
\text { lebih baik } \\
\text { 4. Adanya segmentasi pasar yang sesuai dengan } \\
\text { kebutuhan konsumen } \\
\text { 5. Target pemasaran tertuju secara jelas } \\
\text { 6. Kegiatan pemasaran mempermudah dan } \\
\text { memperlancar penyampaian produk kepada } \\
\text { konsumen }\end{array}$ & $\begin{array}{l}\text { 1. Memanfaatkan keterampilan tenaga kerja untuk } \\
\text { mencapai target pemasaran agar segmentasi pasar } \\
\text { terpenuhi sesuai kebutuhan konsumen (S2, S4, S7, O1, } \\
\text { O3, O6) } \\
\text { 2. Menjaga kualitas bahan baku dalam mempertahankan } \\
\text { loyalitas konsumen agar memperlancar penyampaian } \\
\text { produk konsumen. (S1, S3, S5, S6, O2, O4, O5) }\end{array}$ & $\begin{array}{l}\text { 1. Memanfaatkan loyalitas konsumen dalam } \\
\text { mempertahankan harga produk yang relatif mahal (W1, } \\
\text { W2, W3, W4, O1, O2, O5) } \\
\text { 2. Memanfaatkan segmentasi pasar yang tepat untuk } \\
\text { mendirikan oulet resmi agar meningkatkan penjualan } \\
\text { (W1, W3, O4, O5, O6) }\end{array}$ \\
\hline Ancaman (Treathts) T & Strategi ST & Strategi WT \\
\hline $\begin{array}{l}\text { 1. Banyaknya pesaing dengan produk sejenis } \\
\text { 2. Pesaing yang selalu berinovasi } \\
\text { 3. Belum memiliki ekspedisi }\end{array}$ & $\begin{array}{l}\text { 1. Menjaga kualitas dan stabilitas bahan baku agar produk } \\
\text { dapat bersaing (S1, S2, S4, S5, S5, S6, T1, T2) } \\
\text { 2.Meningkatkan keterampilan tenaga kerja serta } \\
\text { memanfaatkan media promosi secara online dan offline } \\
\text { untuk menghadapi persaingan. (S2, S3, S4, S5, S7, T3, } \\
\text { T2) }\end{array}$ & $\begin{array}{l}\text { 1. Melakukan perbaikan sistem manajemen akuntansi dan } \\
\text { operasional guna menekan harga kopi yang cenderung } \\
\text { mahal. (W2, W3, W4, T1, T2, T3) }\end{array}$ \\
\hline
\end{tabular}

Figure 2. Matriks SWOT 


\subsubsection{Hasil Analisis Quantitative Stategic Planning Matrix (QSPM)}

Setelah menentukan beberapa rumusan alternatif strategi yang sudah dirumuskan, maka langkah selanjutnya adalah melakukan pengambilan keputusan yang merupakan tahap terakhir, dimana pengambilan keputusan ini diambil untk memilih strategi apa yang cocok dan sesuai agar dapat digunakan perusahaan dengan menggunakan matriks Quantitative Stategic Planning (QSPM). Matriks ini juga digunakan untuk mengevaluasi dan meringkas berbagai macam rumusan alternatif strategi secara objektif berdasarkan fakto-faktor internal dan eksternal perusahaan yang telah didapat. QSPM diperoleh dengan melakukan perhitungan mengalikan rata-rata bobot dari masing-masing identifikasi lingkungan internal da eksternal perusahaan dengan nilai daya tarik (AS) sehingga dapat diperoleh nilai total daya tarik (TAS)

Berdasarkan hasil analisis perhitungan TAS tersebut, dapat disimpulkan bahwa strategi yang menjadi prioritas utama yang akan dilakukan oleh UMKM Zhibond Coffee yaitu menjaga kualitas dan stabilitas bahan baku agar produk dapat bersaing dengan skor TAS sebesar 4,50. Alternatif strategi tersebut lebih diprioritaskan oleh UMKM Zhibond Coffee karena dengan semakin ketatnya persaingan didunia bisnis, dimana UMKM Zhibond Coffee harus terus menjaga dan meningkatkan kualitas produk agar dapat bersaing di pasar. UMKM Zhibond Coffee bermitra dengan beberapa petani, diantaranya melakukan kerjasama secara intens yaitu Kebun Rakyat Durjo, Kebun Ijen dan Kebun Tanggul. Sebelum melakukan kerjasama, para petani dilakukan pembinaan terlebih dahulu oleh tenaga kerja UMKM Zhibond Coffee. Hal ini dilakukan agar petani dapat menghasilkan kopi yang berkualitas sesuai dengan grade yang telah ditetapkan oleh perusahaan.
3.1.8. Peringkat Alternatif strategi UMKM Zhibond Coffee

\begin{tabular}{|c|c|c|c|}
\hline No & Alternatif Strategi & $\begin{array}{l}\text { Skor } \\
\text { TAS } \\
\end{array}$ & Rating \\
\hline 1 & $\begin{array}{l}\text { Memanfaatkan keterampilan } \\
\text { tenaga kerja untuk mencapai } \\
\text { pemasaran agar segmentasi } \\
\text { pasar terpenuhi sesuai } \\
\text { kebutuhan konsumen }\end{array}$ & 4,07 & 5 \\
\hline 2 & $\begin{array}{l}\text { Menjaga kualitas bahan baku } \\
\text { dalam mempertahankan } \\
\text { loyalitas konsumen agar } \\
\text { memperlancar penyampaian } \\
\text { produk konsumen }\end{array}$ & 4,24 & 3 \\
\hline 3 & $\begin{array}{l}\text { Memanfaatkan loyalitas } \\
\text { konsumen dalam } \\
\text { mempertahankan harga } \\
\text { produk yang relatif mahal }\end{array}$ & 3,46 & 7 \\
\hline 4 & $\begin{array}{l}\text { Memanfaatkan segmentasi } \\
\text { pasar yang tepat untuk } \\
\text { mendirikan oulet resmi agar } \\
\text { meningkatkan penjualan }\end{array}$ & 4,22 & 4 \\
\hline 5 & $\begin{array}{l}\text { Menjaga kualitas dan } \\
\text { stabilitas bahan baku agar } \\
\text { produk dapat bersaing }\end{array}$ & 4,50 & 1 \\
\hline 6 & $\begin{array}{l}\text { Meningkatkan keterampilan } \\
\text { tenaga kerja serta } \\
\text { memanfaatkan media promosi } \\
\text { secara online dan offline } \\
\text { untuk menghadapi persaingan }\end{array}$ & 4,28 & 2 \\
\hline 7 & $\begin{array}{l}\text { Melakukan perbaikan sistem } \\
\text { manajemen akuntansi dan } \\
\text { operasional guna menekan } \\
\text { harga kopi yang cenderung } \\
\text { mahal }\end{array}$ & 3,51 & 6 \\
\hline
\end{tabular}

\section{Kesimpulan}

Berdasarkan hasil penelitian yang telah dilakukan mengenai "Strategi Pemasaran Kopi Luwak pada UMKM Zhibond Coffee di Kabupaten Jember", maka dapat disimpulkan bahwa prioritas strategi yang tepat dalam mengembangkan UMKM Zhibond Coffee di Kabupaten Jember yaitu menjaga kualitas dan stabilitas bahan baku agar produk dapat bersaing. 


\section{Daftar Pustaka}

[1] Abdullah, T. dan F, Tantri. 2015. Manajemen Pemasaran.Jakarta: Rajawali Pers.

[2] Amirrullah. 2015. Manajemen Strategi. Jakarta: Mitra Wacana Media.

[3] Badan Pusat Statistik.2018.Statistik Kopi Indonesia Indonesian Coffee Statistic 2018.Hal 10. [17 Juli 2020]

[4] Budiman.2015.Prospek Tinggi Bertanam Kopi : Pedoman Meningkatkan Kualitas Perkebunan Kopi.

[5] David dan Forest.2016.Manajemen Konsep Strategik Suatu Pendekatan Keunggulan Bersaing. Edisi 15. Hal 11. Jakarta: Salemba Empat.

[6] Kasmir. 2014. Kewirausahaan. Cetakan ke-10. Hal 186. Jakarta: Raja Grafindo.

[7] Kementerian Pertanian.2019. Indonesia Negara Penghasil Kopi Keempat di Dunia. [17 Juli 2020]

[8] Kotler, P. dan G. Amstrong. 2008. Prinsip-prinsip Pemasaran Edisi Kedua Belas Jilid 1. Jakarta: Erlangga.

[9] Manap, H. A. 2016. Revolusi Manajemen Pemasaran. Jakarta: Mitra Wacana Media.

[10] Purwanto, I. 2007. Manajemen Strategi. Cetakan ke 3. Bandung: Penerbit Yrama Widya.

[11] Rangkuti, F. 2016. Analisis SWOT: Teknik Membedah Kasus Bisnis. Jakarta: PT Gramedia Pustaka Media.

[12] Sahman, M.P. 2019. Strategi Pemasaran Jual Beli Kopi (Studi di Desa Dandang Kecamatan Sabbang Kabupaten Luwu Utara). Skripsi. Intitus Agama Islam Negeri Palopo. Sulawesi Selatan.

[13] Salitasari, F.2017.Strategi Pemasaran Pia Tape pada UD. Purnama Jati Kecamatan Patrang Kabupaten Jember.Skripsi.Politeknik Negeri Jember. Jember.

[14] Siswoputranto, P.S. 1993. Kopi Internasional dan Indonesia. Yogyakarta: Kanisius.

[15] Sugiyono. 2016. Metode Penelitian Kuantitatif, Kualitatif dan $R \& D$. Bandung: Alfabeta.

[16] Susanti, S.M. 2018. Strategi Pemasaran Kopi Bubuk Robusta di pusat Penelitian Kopi dan Kakao Indonesia. Skripsi. Politeknik Negeri Jember. Jember.

[17] Spillane, J.J. 1990. Komoditi Kopi Peranannya dalam Perekonomian Indonesia. Yoyakarta:Kanisius.

[18] Utami, R.A. 2018. Strategi Pemasaran Kopi Robusta di Kabupaten Temanggung. Skripsi. Universitas Sebelas Maret. Surakarta.

[19] Wahyudi dan Izhar. 2018. Strategi Pemasaran Kopi Arabika Kerinci di Provinsi Jambi.Hal 277. [24 Juli 2020]. 